\title{
Influence of social media marketing in building relationship between brand loyalty of tourism products and products service quality
}

\author{
Yan Jiaqi ${ }^{1}$, Brain Sheng-Xian $\mathrm{Teo}^{2}$, Li Tingting ${ }^{3}$, Zhang Jiaxun ${ }^{4}$ \\ ${ }^{1}$ Management \& Science University, Graduate School of Management, Shah Alam, Selangor, Malaysia \\ ${ }^{2}$ Management \& Science University, Graduate School of Management, Shah Alam, Selangor, Malaysia \\ ${ }^{3}$ Multimedia University, Faculty of Management, Cyberjaya, Selangor, Malaysia \\ ${ }^{4}$ Management \& Science University, Graduate School of Management, Shah Alam, Selangor, Malaysia
}

\begin{abstract}
Social media is an influential objective for most industries. Organizations in every sector are willing to implement this technique for achieving several business goals. Some of them are brand loyalty and service quality. The current study analyses these specific objectives in the tourism sector. The AIDA model has been considered in this scenario, where five hypotheses are generated. Instagram has been selected as the selected social media platform, as $45 \%$ of respondents preferred it. The study includes a primary research method surveying 51 respondents and evaluating the quantitative data using SPSS. The KMO and Bartlett's Test indicated a reading of 0.932 , which describes the reliability of the sample. The statistical value provides that there is a strongly positive relation (R-0.960; R2-0.922; 92.2\%) between tourism brand and product quality in the sector. On the other hand, through Cronbach's alpha, the results came as 0.997, which shows the high level of consistency between the variables. It has been further analysed that brand awareness, brand loyalty, and tourism product service are integral part of business objects that are related to social media marketing.
\end{abstract}

\section{Introduction}

The process of usage of social media marketing (SMM) supports an organization to connect with audiences, to enhance brand image as it supports an increased rate of sales. The SMM supports in attracting new audiences for business, as it supports in opening up doors of tools and tactics thus new audiences can engage with business. The objectives of the research paper are-

- To examine effects of social media marketing activities that supports in increasing brand awareness, image and loyalty

- To signifies different factors that are associated with social media marketing to enhances brand loyalty of tourism sector

- To understand the impacts of social media marketing to establish a positive relationship between brand loyalty of tourism products

\section{Theoretical Background and Hypothesis Development}

Technological convergence has facilitated opportunities for global businesses to operate in the competitive market while utilizing advanced technologies for building brand awareness. The initiative to co-create tourism value through adopting social media marketing strategy can enable a tourism business to reach a larger customer base through creating value proposition [1]. Besides, building and maintaining customer trust in a specific brand, especially for tourism business, can be highly controlled by the brand equity and product quality of respective company. Regarding this, social media marketing helps to build brand consumer relationship model for enhancing brand awareness [2].

Now, following the theoretical concept of $\boldsymbol{A I D A}$ model, brand loyalty and marketing performance of a brand can be controlled through successful implementation of marketing strategies [3]. In this case, the first stage concentrating on developing awareness of proposed products or services by a specific brand helps businesses to device appropriate marketing strategies. This is further followed by the interests of customers as introducing social media marketing tools and platforms enables a business to reach a wider customer base [4].

\footnotetext{
* Corresponding author: 564593809@qq.com
} 


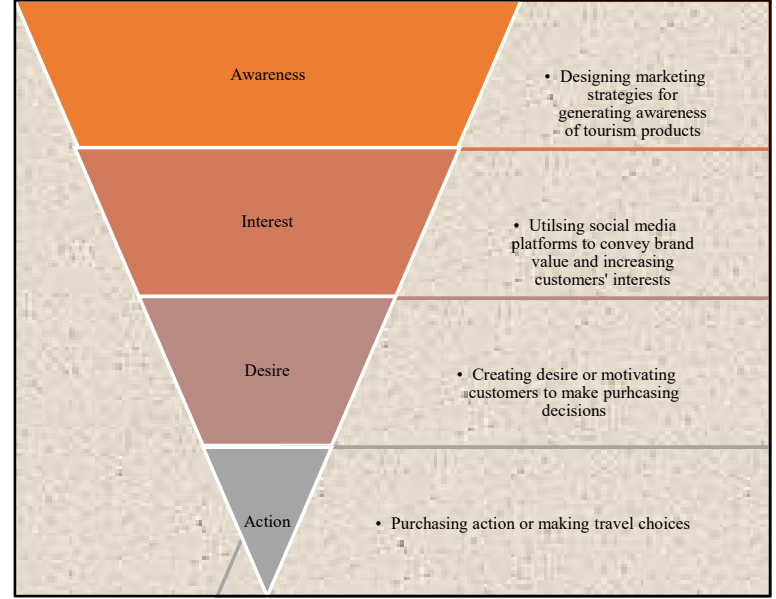

Figure 1: AIDA Model of Brand Awareness

Along with this, encouraging customers to make purchasing decisions through motivating the customers and informing them regarding product features can be supportive to design build brand loyalty through improving service quality. This is also influenced by the perceived value and perceived experience of customers regarding a specific brand for meeting tourism service quality and acquiring more loyal customers [5]. Depending on this, the role of social media being an essential marketing tool to build relationship between tourism brand loyalty and product service quality is essential to consider. Here, the hypothesis to be tested in this study can be listed as below-

H1: Social media marketing holds significant impact on building brand awareness

$\mathrm{H} 2$ : Social media marketing holds significant impact on building brand loyalty

H3: Social media marketing holds significant impact on conveying the tourism products and services quality

Now, considering this, the following parallel hypothesis have been determined to develop a better idea regarding this research context-

H4: Brand awareness through social media marketing holds significant impact on brand loyalty of tourism product service

H5: Brand awareness through social media marketing holds significant impact on tourism product service quality

\section{Materials and Methods}

\subsection{Research Method and Research Model}

The social media strategy supports increased brand recognition as it engages with broad audiences of consumers. Quantitative methods of data collection are applied to gain an understanding about marketing activities and loyalty possessed by brands of tourism products. Usage of quantitative methods supports in understanding all complex reality associated with a topic, as it supports in obtaining accurate and reliable measurement [6]. The usage of quantitative methods influences social media marketing as it supports in building relationships between tourism services and product services. Usage of input and output research methods leads to a positive emphasis as it supports in objective measurement and statistical analysis of all collected data. Hence, it can be stated that research methods is primary quantitative and research models can be proposed as below.

\subsection{Population and Sampling}

The research population can be highlighted as a collection of population from large collection, as it supports in putting an effective focus on maintaining scientific query. The research population supports a well-defined collection of individuals and objects and the research study is effectively relied on these sampling techniques [7]. The applied sampling technique, random sampling, supports in highlighting unbiased representation of total population by selecting 51 customers out of total populations that are present within the travel industry.

\subsection{Measurement}

Quantitative methods effectively emphasize objective measurement, process thus all issues can be managed in a much effective manner. The process of computational techniques supports in managing some of statistical data, as it leads to development of quantitative research methods. The research data supports in measuring all issues in a much effective manner, as it supports in managing all issues [8]. In the data collection methods, the researcher has progressed for conduction primary methods of data collections.

In this research paper, the researcher questionnaire has divided the question into four parts. The first part of survey question is significantly focused on highlighting interaction processes and its benefit can be obtained with help of SMM [9]. The process of interaction supports in brand visibility and supports in increment in tourism products.

\subsection{Data Collection and Analysis}

The data collection is a process of collecting, analyzing and measuring accurate data therefore the process of standard validation techniques can be conducted. In this research paper, for concluding study in effective manner primary methods of data collection is done. The adoption of primary methods of data collection supports resolving all research issues, thus all specific issues can be met to resolve all issues to enhance business situations [10]. The data analysis is been conducted with help of SPSS, as it supports in providing some reliable and fast answers. Hence, primary methods of data collection are done on 51 respondents of customers and tourists, whereas analysis is done on SPSS. 


\section{Results \& Discussion}

\subsection{Demographic Characteristics}

In order to comment on the effectiveness of social media in building relationship between tourism brand loyalty and tourism product and service quality, statistical analysis have been performed. Here, demographic characteristics of chosen participant group highlights that out of 51 respondents $57 \%$ of the employees (29) were female while $35 \%$ and $8 \%$ of employees were male and others respectively. Moreover, $33 \%$ of respondents belong from the age group of $35-44$ while $51 \%$ were in the age group of 25 to 34 years. Besides, Instagram has been preferred as the most frequently used social media platform to extract information on tourism places as $45 \%$ of the participants have chosen this option.

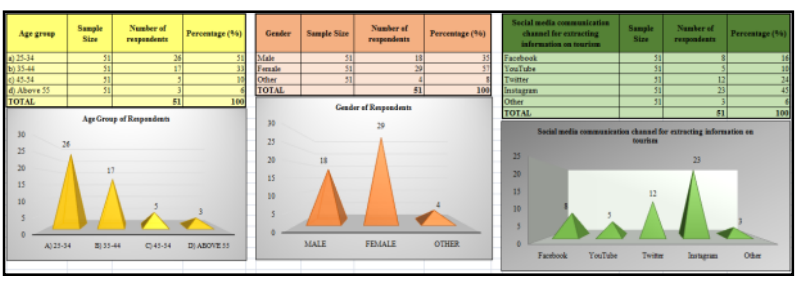

Figure 2: Demographic Data

\subsection{Measurement Model}

In order to test the hypothesis and comment on the influence of social media in building relationship between brand loyalty of tourism products and product service quality, it is essential to test the validity of measurement. Moreover, measuring the internal consistency of the factor while assessing the conformity of the data set it can be stated that supportive coverage validity of measurement model. In this context, performing KMO and Bartlett's Test has assisted to test the sampling adequacy of data used for factor analysis [11].

Table 1. KMO and Bartlett's Test for Factor Analysis

\begin{tabular}{|c|c|c|}
\hline \multicolumn{3}{|c|}{ KMO and Bartlett's Test } \\
\hline \multicolumn{2}{|c|}{ Kaiser-Meyer-Olkin Measure of Sampling Adequacy. } & .932 \\
\hline \multirow[t]{3}{*}{ Bartlett's Test of Sphericity } & Approx. Chi-Square & 943.672 \\
\hline & df & 21 \\
\hline & Sig. & .000 \\
\hline
\end{tabular}

As indicated in the table presented above, the value for sampling adequacy in KMO and Bartlett's test is 0.932 , which is greater than 0.05 . This indicates that the factor analysis is useful with the obtained data signifying the adequacy of sampling data. Apart from that, intention to test the measurement model has been justified through conducting reliability analysis for obtaining and interpreting Cronbach's Alpha value and test the internal consistency of gathered data set [12].
Table 2. Cronbach's Alpha Test

\begin{tabular}{|c|c|c|}
\hline \multicolumn{3}{|c|}{ Reliability Statistics } \\
\hline $\begin{array}{c}\text { Cronbach's } \\
\text { Alpha }\end{array}$ & $\begin{array}{c}\text { Cronbach's } \\
\text { Alpha Based } \\
\text { on } \\
\text { Standardized } \\
\text { Items }\end{array}$ & $\mathrm{N}$ of Items \\
\hline .997 & 997 & 17 \\
\hline
\end{tabular}

Now, as indicated in the above table, a total number of 17 items have been selected in this study, which represents that all of these factors have been considered to ensure the reliability of the measurement model. Besides, the Cronbach's alpha being 0.997 highlights that there is high level of internal consistency for the chosen scale with this particular sample.

Table 3. Item Total Statistics

\begin{tabular}{|c|c|c|c|c|}
\hline \multicolumn{5}{|c|}{ Item-Iotal Statistics } \\
\hline & $\begin{array}{c}\text { Scale } \\
\text { Mean } \\
\text { if Item } \\
\text { Delete } \\
d\end{array}$ & $\begin{array}{c}\text { Scale } \\
\text { Varianc } \\
\text { e if } \\
\text { Item } \\
\text { Deleted }\end{array}$ & $\begin{array}{l}\text { Corrected } \\
\text { Item- } \\
\text { Total } \\
\text { Correlati } \\
\text { on }\end{array}$ & $\begin{array}{l}\text { Cronbach } \\
\text { 's Alpha } \\
\text { if Ittem } \\
\text { Deleted }\end{array}$ \\
\hline $\begin{array}{l}\text { @4Twowaycommunicationhasbeenpossibleusingsocial } \\
\text { media }\end{array}$ & 44.82 & $\begin{array}{r}417.26 \\
8\end{array}$ & .983 & .997 \\
\hline @SExchangingpersonalviewsonabrandhasbeenincreased & 45.00 & $\begin{array}{r}422.56 \\
0\end{array}$ & .955 & 997 \\
\hline $\begin{array}{l}\text { @6Birandaddsinsocialmediaplatformsmakeproductsreco } \\
\text { gnisab| }\end{array}$ & 44.75 & $\begin{array}{r}417.95 \\
4 \\
\end{array}$ & .985 & .997 \\
\hline @7 Advertisementspublishedinsocialmediaareinteresting & 44.98 & $\begin{array}{r}417.26 \\
0 \\
\end{array}$ & .976 & 997 \\
\hline $\begin{array}{l}\text { @8Socialmediaadvertisementshelpedtocreatepositivebra } \\
\text { ndi }\end{array}$ & 44.61 & $\begin{array}{r}421.84 \\
3 \\
\end{array}$ & .971 & .997 \\
\hline $\begin{array}{l}\text { (a9:Socialmediahelpedtoprovidedetailedproductinformati } \\
\text { on }\end{array}$ & 44.84 & 415.53 & .979 & .997 \\
\hline $\begin{array}{l}\text { @10Presenceofbrandsonsocialmediaplatformsensuredea } \\
\text { syac }\end{array}$ & 44.63 & $\begin{array}{r}418.35 \\
8 \\
\end{array}$ & .972 & .997 \\
\hline @11Socialmediahashelpedtoimproveinformationsharing & 44.73 & $\begin{array}{r}417.12 \\
3\end{array}$ & .982 & .997 \\
\hline $\begin{array}{l}\text { @112Quickelectroniccommunicationofcontenthroughsoc } \\
\text { ialmed }\end{array}$ & 44.80 & 416.72 & .986 & .997 \\
\hline $\begin{array}{l}\text { @13Presenceinsocialmediahelpstoconveythebrandchara } \\
\text { cter }\end{array}$ & 44.98 & $\begin{array}{r}417.58 \\
0\end{array}$ & .970 & 997 \\
\hline $\begin{array}{l}\text { @14Designingsocialmediacampaignsstrengthsthebrandi } \\
\text { mage }\end{array}$ & 44.94 & $\begin{array}{r}414.85 \\
6 \\
\end{array}$ & .980 & .997 \\
\hline $\begin{array}{l}\text { @15Socialmediamarketingmakescustomersawareoforan } \\
\text { dlogof }\end{array}$ & 44.67 & 420.50 & .980 & 997 \\
\hline $\begin{array}{l}\text { @16Customercentricproductandserviceapproachensuresl } \\
\text { ongt }\end{array}$ & 44.75 & 422.87 & .962 & .997 \\
\hline $\begin{array}{l}\text { @17Effectivecustomerrelationshiphelpstomakebetterbra } \\
\text { ndc }\end{array}$ & 44.84 & $\begin{array}{r}423.69 \\
5\end{array}$ & .965 & .997 \\
\hline $\begin{array}{l}\text { @18Promotingbrandonsocialmediaplatformscreatesgood } \\
\text { memor }\end{array}$ & 44.78 & $\begin{array}{r}415.77 \\
3\end{array}$ & .985 & 997 \\
\hline $\begin{array}{l}\text { @19Socialmediamarketingcanhelptoshapebrandappeara } \\
\text { nce }\end{array}$ & 44.75 & $\begin{array}{r}422.95 \\
4\end{array}$ & .975 & .997 \\
\hline @20Socialmediamarketinghelpstocreatevaluepropositio & 44.86 & 414.08 & .982 & .997 \\
\hline
\end{tabular}

The attached table helps to interpret the results if an item would be deleted from the table. Here, the removal of any of the factors or variables can hold significant impact on the data set as the vales of Cronbach's alpha for all of the questions are high (more than 0.950). Therefore, it can be mentioned that removal of any of these items can influence the statistical outcomes.

\subsection{Structural Model}

Social media marketing enabling opportunity for tourism industry to build better customer relationship can influence the customers' perceived brand value [13]. Now, following this specific context, paired-sample ttest has been performed for testing the hypothesis and 
comment on the influence of social media marketing in developing effective relationship between tourism brand loyalty and product service quality.

Table 4. Paired Sample Test

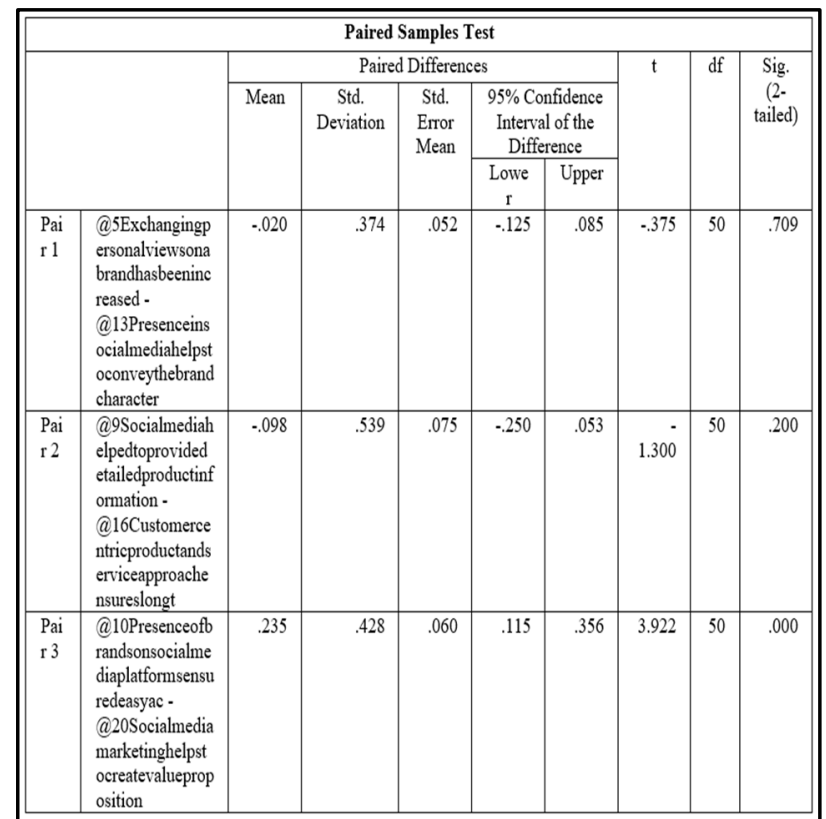

The table shows that mean value for the first chosen pair is -0.20 while the standard deviation is 0.374 and $\mathrm{t}$ value is -0.375 . Now, a $95 \%$ confidence level being considered here with a significance level of 0.709 that is more than 0.05 highlights that there can be other factors influencing brand awareness rather than only social media marketing. The same thing applied for the t-test with the second pair as the $\mathrm{p}$ value presented here is 0.2 . However, the p-value of the third pair is 0.000 $(0.000<0.05)$ and this indicates that there is statistically significant different between the chosen two variables, which are questions 10 and 20.

On the other hand, in order to comment on the interrelationship between tourism brand loyalty and product service quality, a multiple regression test has been performed.
Table 5. Model Summary

\begin{tabular}{|c|c|c|c|c|}
\hline \multicolumn{5}{|c|}{ Model Summary } \\
\hline $\begin{array}{l}\text { Mode } \\
1\end{array}$ & $\mathrm{R}$ & $\begin{array}{c}\mathrm{R} \\
\text { Squar } \\
\mathrm{e}\end{array}$ & $\begin{array}{c}\text { Adjuste } \\
\text { d R } \\
\text { Square }\end{array}$ & $\begin{array}{c}\text { Std. } \\
\text { Error of } \\
\text { the } \\
\text { Estimate }\end{array}$ \\
\hline 1 & $.960^{\mathrm{a}}$ & .922 & .919 & .351 \\
\hline
\end{tabular}

a. Predictors: (Constant),

@19Socialmediamarketingcanhelptoshapebrandappe arance,

@17Effectivecustomerrelationshiphelpstomakebetter brandc

The table shows the value of $\mathrm{R}(0.960)$ indicating a strongly positive relationship between the research variables while R2 value being 0.922 indicates that $92.2 \%$ data can be explained.

Table 6. ANOVA Table

\begin{tabular}{|c|c|c|c|c|c|c|}
\hline \multicolumn{7}{|c|}{ ANOVA $^{a}$} \\
\hline \multicolumn{2}{|c|}{ Model } & Sum of & df & Mean & $\mathrm{F}$ & Sig. \\
\hline \multirow[t]{3}{*}{1} & Regression & 70.071 & 2 & 35.035 & 283.63 & $.000^{\mathrm{b}}$ \\
\hline & Residual & 5.929 & 48 & .124 & & \\
\hline & Total & 76.000 & 50 & & & \\
\hline \multicolumn{7}{|c|}{ a. Dependent Variable: } \\
\hline & $\begin{array}{l}\text { redictors: (C) } \\
\text { Socialmedia }\end{array}$ & $\begin{array}{l}\text { unt), } \\
\text { cetingcanhely } \\
\text { errelationship }\end{array}$ & shap & andappe & $\begin{array}{l}\text { nce, } \\
\text { ndc }\end{array}$ & \\
\hline
\end{tabular}

Here, the ANOVA table represents that the $\mathrm{p}$ value, presented in "Sig." column of "Regression" row is 0.000 and this value being smaller than $0.05 \quad(0.000>0.05)$ signifies that the regression model can statistically significantly predict the outcome variable. 
Table 7. Correlation Coefficient Table

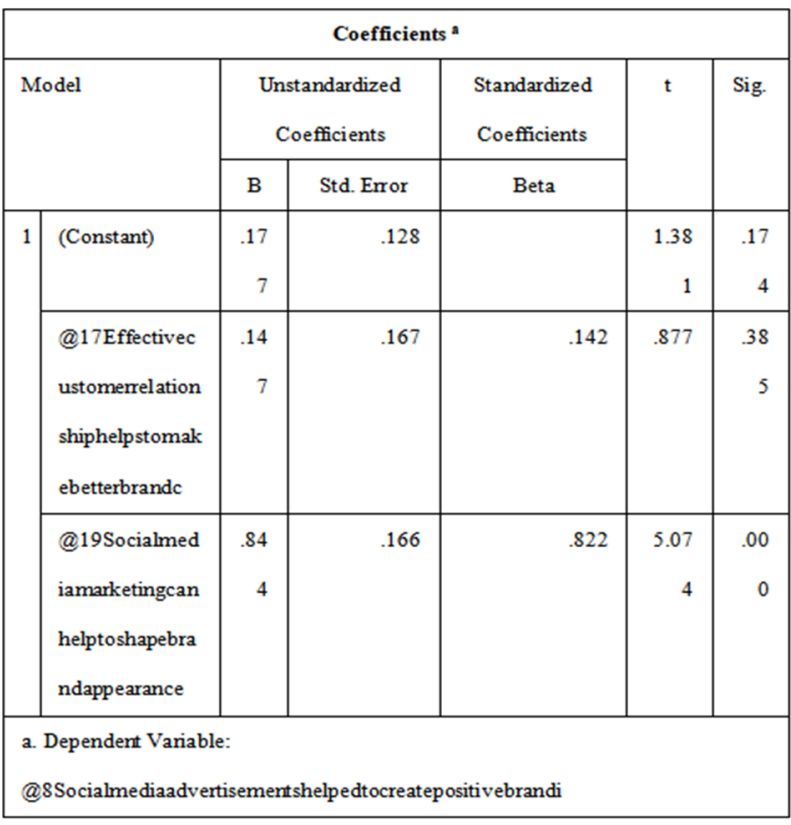

In addition, following the above table, it is evident that the chosen dependent (question 8) and independent variables (questions 17 and 19) share statistically significant relationship and hence, the regression equation can be presented as below-

Question 8= 0.177+0.147 (Question 17) + 0.844

\section{(Question 19)}

Therefore, it can be interpreted that there is strongly statistical positive relationship between the dependent variable (social media marketing) and independent variables (brand loyalty and tourism product service quality). Thus, it accepts the hypotheses and establishes that adoption of social media marketing strategies can be beneficial for businesses to enhance customer awareness for building tourism brand loyalty [14]. Furthermore, based on the statistical assessment carried out in previous section, it can be mentioned that social media can work as an essential tool to develop a relationship between tourism brand loyalty and product service quality

Depending on this, the structural model can be presented as below-

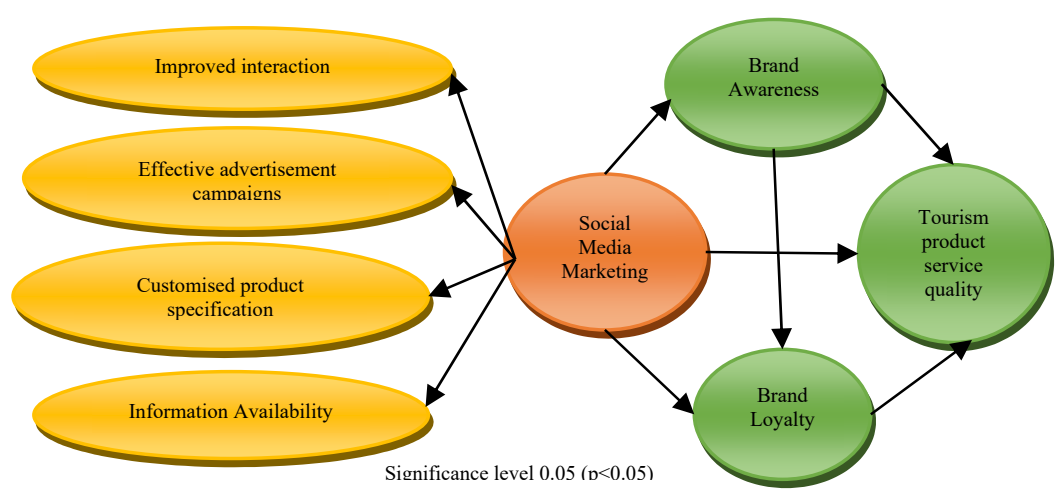

Figure 3: Research Mode

\section{Interpretations}

\subsection{Social Media Marketing Activities and Brand Awareness of Tourism Products}

Social Media Marketing (SMM) supports the usage of social media platforms to connect with audiences to increase brand sales and supports in attracting website traffic. The usage of social media marketing activities supports in increasing brand awareness as it supports in attracting inbound traffic and supports in improvement of search engine ranking. The usage of SMM supports in increasing conversion rates thus leads to an improvement of brand loyalty and brand authority. Social media supports interacting with content as it supports increased brand awareness, as it supports in enhancing cost-efficiency of organizations operating within digital marketing. The usage of SMM supports in usage of social media websites, thus marketing can be done on services and products.

Effective usage of social media marketing (SMM) supports interactive multitasking as it is effectively dependent on network participation. The SMM effectively supports in connecting with audiences, as it supports in supplementing network participation and supports in conduction of striking discoveries of information technology. The usage of social media improves the process of interaction with consumers as it supports effective improvement of performances of consumers. For instance, VisitBritain has collected about 1.9 billion GBP extra due to investment in overseas performances. Effective usage of social media marketing strategy has helped Visit Britain to conduct campaigns as it supports an increasing rate of visit by $10 \%$ [17]. Therefore, the usage of SMM activities supports in development of effective advertising campaigns as it supports in managing issues.

Social media marketing (SMM) supports in improving interaction between both customers and organizations. The social media usage has become ubiquitous and organizations with help of SMM can able to meet strategic goals, as it supports in managing customer relationship management processes. The interaction with customers supports in creating customer engagement as it enhances firm performances as it leads to development of marketing strategies [18]. On the other hand, about 45 million of social media users are 
using social media as it leads to highlights that effectively $66 \%$ of UK are using social media [19]. Therefore, it can be stated that customization of product specification supports in improvement of performances of an organization. The usage of social media supports organizations to gain an effective understanding about needs of customers. The usage of SMM supports in increasing the rate of availability as it supports in managing and highlighting product specialization. Hence, it can be stated that usage of SMM supports in improvement of tourism product specification as it supports in enhancement of performance of tourism industry.

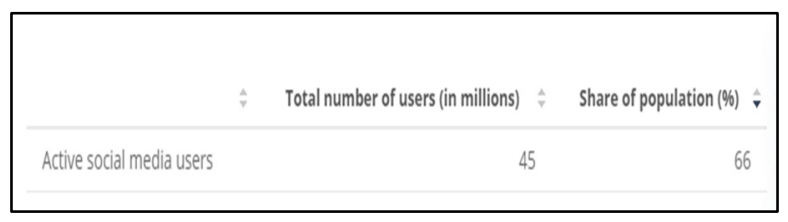

Figure 4: Active number of social media users in UK

\subsection{Relationship between Tourism Branding and Tourism Product Service Quality}

The process of social media marketing holds a significant marketing effect as it supports in improvement of product quality and services. In this modern day, tourism branding and service quality improvement takes place as it supports in managing all issues in a much effective manner. Adoption of tourism branding and tourism service quality leads to a positive relationship as it enhances brand awareness and brand loyalty. The adoption of SMM supports in improvement of tourism product service quality with help of interactive interaction with consumers [20]. The usage of the SMM supports in establishing a relationship between tourism branding and tourism product service quality as it supports in motivating customers and informing product features to build a loyal brand.

The process of conduction of business is effectively dependent on making powerful tools, thus potential customer development process can be done as it supports in having a proper reputation. The branding effectively focused on improving the recognition as it supports in development of trust between customer and audiences. The process of SMM supports as a backbone of advertisement process as it leads to development of tourism branding and supports ion having a proper service quality [22]. The process of branding supports and inspires employees as it supports brands to draw happy customers. The process of branding creates differentiates as it supports effective management of branding processes as differentiates of competitors can be done. The usage of SMM supports brand strategy as it supports in managing all issues and identifying target audiences.

Tourism branding is a powerful weapon that supports in identification of idea and feeling as it supports in conduction of brand strategy. The target audience identification supports in highlighting positioning statements, as it supports in development of complex brand situations. The process of quality content supports in long term brand development as it supports effective management of unique contacts [23]. The tourism products and service quality is effectively influenced in enhancing performances, as brand building supports in managing internal brand launch.

\section{Conclusion}

The web conference has provided a view point about convergences and facilitative opportunities as it supports in managing all issues and provides advanced technologies to manage all the factors in much sequential manner. Social media marketing has a direct impact on improving the rate of interaction, as it supports in managing campaigns. The topic of the research paper is influences of Social Media Marketing in Building relationships as it supports in managing brand loyalty of tourism products and service quality. The report significantly highlights social media marketing as it supports in providing effective information in a much effective manner.

The usage of social media marketing supports custom product specification as it leads to effective management of information in much effective manner. In this research paper, the researcher has tried to highlights about SMM as it supports in managing brand tourism as it effectively supports in reducing rate of intervention and management performances. In this research paper, the researcher has tried to showcase all the fundamental performances of all significant findings as it supports in managing issues in effective manner.

\section{Acknowledgement}

The topic 'Influence of Social Media Marketing in Building Relationship between Brand Loyalty of Tourism Products and Products Service Quality' is an essential factor in the current business world, and has significantly helped me in analyzing the concept as well. I would like to show my gratitude to the people, who have constantly assisted me in commencing and finishing this research. I am thankful towards my professor, who has helped me in selecting the topic. Further, I am grateful to my friends who have helped me in collecting proper data and assisted in analyzing the information properly; and proofread my entire thesis. I would also like to thank my family, who were beside me and encouraged me to complete the research on time.

\section{References}

1. Carlson, J., Wyllie, J., Rahman, M.M. and Voola, R., 2019. Enhancing brand relationship performance through customer participation and value creation in social media brand communities. Journal of Retailing and Consumer Services, 50, pp.333-341.

2. Bilgin, Y., 2018. The effect of social media marketing activities on brand awareness, brand 
image and brand loyalty. Business \& Management Studies: An International Journal, 6(1), pp.128-148.

3. Prathapan, M., Sajin Sahadevan, D. and Zakkariya, K.A., 2018. Effectiveness of digital marketing: Tourism websites comparative analytics based on AIDA model. International Journal of Innovative Research \& Studies, 8(4), pp.262-273.

4. Chatzigeorgiou, C., 2017. Modelling the impact of social media influencers on behavioural intentions of millennials: The case of tourism in rural areas in Greece. Journal of Tourism, Heritage \& Services Marketing (JTHSM), 3(2), pp.25-29.

5. Suseno, Y., Laurell, C. and Sick, N., 2018. Assessing value creation in digital innovation ecosystems: A Social Media Analytics approach. The Journal of Strategic Information Systems, 27(4), pp.335-349.

6. Queirós, A., Faria, D. and Almeida, F., 2017. Strengths and limitations of qualitative and quantitative research methods. European Journal of Education Studies.

7. Beketov, M., Lehmann, K. and Wittke, M., 2018. Robo Advisors: quantitative methods inside the robots. Journal of Asset Management, 19(6), pp. 363-370.

8. Sablan, J.R., 2019. Can you really measure that? Combining critical race theory and quantitative methods. American Educational Research Journal, 56(1), pp.178-203.

9. Duffett, R.G., 2017. Influence of social media marketing communications on young consumers' attitudes. Young Consumers.

10. Zhou, D., Yan, Z., Fu, Y. and Yao, Z., 2018. A survey on network data collection. Journal of Network and Computer Applications, 116, pp.9-23.

11. Napitupulu, D., Kadar, J.A. and Jati, R.K., 2017. Validity testing of technology acceptance model based on factor analysis approach. Indonesian Journal of Electrical Engineering and Computer Science, 5(3), pp.697-704.

12. Chan, L.L. and Idris, N., 2017. Validity and reliability of the instrument using exploratory factor analysis and Cronbach's alpha. International Journal of Academic Research in Business and Social Sciences, 7(10), pp.400-410.

13. Hidayanti, I., Herman, L.E. and Farida, N., 2018. Engaging customers through social media to improve industrial product development: the role of customer co-creation value. Journal of Relationship Marketing, 17(1), pp.17-28.

14. Alghizzawi, M., Salloum, S.A. and Habes, M., 2018. The role of social media in tourism marketing in Jordan. International Journal of Information Technology and Language Studies, 2(3), pp.59-70.

15. Kayumovich, K.O. and Kamalovna, S.F., 2019. Social media-marketing-a forceful tool for tourism industry. European science, (7 (49)).

16. Iankova, S., Davies, I., Archer-Brown, C., Marder, B. and Yau, A., 2019. A comparison of social media marketing between B2B, B2C and mixed business models. Industrial Marketing Management, 81, pp.169-179.
17. visitbritain.org, 2019. Our annual performance \& reporting Available At:

https://www.visitbritain.org/our-performancereporting

18. Wang, Z. and Kim, H.G., 2017. Can social media marketing improve customer relationship capabilities and firm performance? Dynamic capability perspective. Journal of Interactive Marketing, 39, pp.15-26.

19. Tankovska, H., 2021. UK: active social media users 2020. https://www.statista.com/statistics/507405/ukactive-social-media-and-mobile-social-mediausers/\#: :text $=$ The $\% 20$ United $\% 20 \mathrm{Kingdom} \% 20$ (U K) $\% 20$ was, the $\% 20$ population $\% 20$ of $\% 20$ the $\% 20$ UK .\&text $=$ The $\% 20$ level $\% 20$ of $\% 20$ social,puts $\% 20$ it $\% 2$ 018th\%20overall\%20worldwide.

20. Bhor, H.N., Koul, T., Malviya, R. and Mundra, K., 2018, January. Digital media marketing using trend analysis on social media. In 2018 2nd International Conference on Inventive Systems and Control (ICISC) (pp. 1398-1400). IEEE.

21. Hultman, M., Ulusoy, S. and Oghazi, P., 2019. Drivers and outcomes of political candidate image creation: The role of social media marketing. Psychology \& Marketing, 36(12), pp.1226-1236.

22. Bhor, H.N., Koul, T., Malviya, R. and Mundra, K., 2018, January. Digital media marketing using trend analysis on social media. In 2018 2nd International Conference on Inventive Systems and Control (ICISC) (pp. 1398-1400). IEEE. 